Pankiv M. V., Paltov Ye. V., Masna Z. Z. Structural components of the normal thoracic and lumbar vertebrae in rats. Journal of Education, Health and Sport. 2021;11(1):163-169. eISSN 2391-8306. DOI http://dx.doi.org/10.12775/JEHS.2021.11.1.016 https://apcz.umk.pl/czasopisma/index.php/JEHS/article/view/JEHS.2021.11.1.016

https://zenodo.org/record/4476516

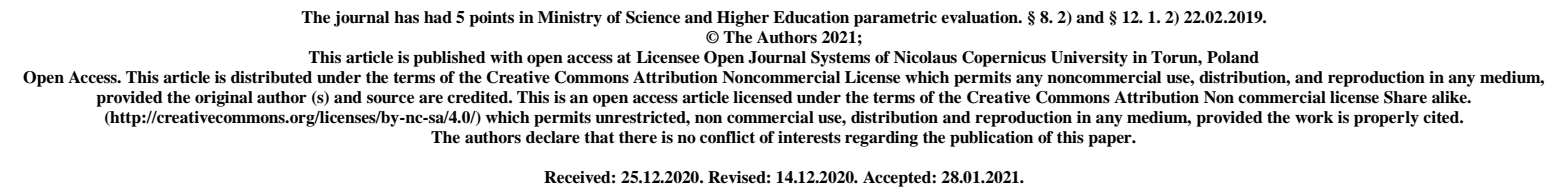

UDK: 611.711/.712.018.3.019

\title{
Structural components of the normal thoracic and lumbar vertebrae in rats
}

\author{
M. V. Pankiv, Ye. V. Paltov, Z. Z. Masna
}

\author{
Danylo Halytsky Lviv National Medical University, Lviv, Ukraine
}

\begin{abstract}
M. V. Pankiv, PhD-student at the Department of Normal Anatomy, Danylo Halytsky Lviv National Medical University, Lviv, Ukraine, https://orcid.org/0000-0002-3714-2577

Ye. V. Paltov, Ph.D., Associate Professor, Head of the Laboratory of Electron Microscopy, Danylo Halytsky Lviv National Medical University, Lviv, Ukraine, https://orcid.org/0000-0002-2622-4753 Z. Z. Masna, MD, Professor, Head of the Department of Operative Surgery and Topographical Anatomy, Danylo Halytsky Lviv National Medical University, Lviv, Ukraine, https://orcid.org/0000-0003-2057-7061
\end{abstract}

\section{Abstract}

The relevance of this topic is determined by the fact that laboratory animals are widely used in experimental morphology. The most widely used ones are rats [1 - 7]. There are a number of studies in which the authors cover in detail the normal morphological state of various organs of rats and its changes under experimentally simulated pathological conditions [8 - 12]. The available studies on the rats' musculoskeletal system and spine highlight this topic insufficiently. Aim. We aimed to study the structure of the normal thoracic and lumbar vertebrae in the rats. Materials and methods of research. The objects of our study were 15 sexually mature outbred male rats, weight $80 \mathrm{~g}$, age 4,5 months. All animals were kept in a vivarium. Keeping, care, labeling, and all other manipulations were carried out in accordance with with 'the European Convention for the Protection of Vertebrate Animals Used for 
Experimental and Other Scientific Purposes' [Strasbourg, 1985], 'Ethical principles of animal experiments', approved by the First National Congress on Bioethics [Kyiv, 2001], Law of Ukraine № 3447 - IV 'On protection of animals from cruel treatment'. The study was approved by the Commission on Bioethics of Danylo Halytsky Lviv National Medical University which declared that the study met the ethical requirements according to the order of the Ministry of Health of Ukraine № 231 of November 1, 2000 (protocol № 10 of December 26, 2011), (protocol №2 of February 20, 2012 year). Before sampling, the animals were sedated with dibutyl ether. Skeletalized rat bones were used as material for the macroanatomical study of the structural components of the thoracic and lumbar vertebrae. The spines were dissected after euthanasia, and then the vertebrae of the thoracic and lumbar spine were boiled for four hours, followed by careful separation of the remained soft tissues. The obtained bones were treated with a solution of hydrogen peroxide with the following photography in different projections in order to identify all anatomical structures involved in the formation of thoracic and lumbar vertebrae. Photography was made using a digital camera Nikon D 3100. Results. The study of 15 spinal column preparations of white, outbred male rats weighing $80 \mathrm{~g}$, aged 4.5 months made by the use of a set of morphological methods revealed a lot of aspects of the normal structural components of the vertebrae of the lower thoracic and lumbar spine of rats. The spinal column of the rat consists of a set of vertebrae that form its divisions. There are 57 vertebrae in the rat spine. The cervical division is represented by 7 vertebrae, thoracic - 13, lumbar - 6, sacral - 4 and caudal - 27 vertebrae. Conclusions: As a result of our study, we identified the morphology of normal vertebrae of the thoracic and lumbar spine in rats. We studied a set of morphological components of the thoracic and lumbar vertebrae of the normal spinal column in rats.

\section{Keywords: morphology; thoracic and lumbar spine; normal state; rat.}

Introduction. The relevance of this topic is determined by the fact that laboratory animals are widely used in experimental morphology. The most widely used ones are rats [1 7]. There are a number of studies in which the authors cover in detail the normal morphological structure of various organs of rats and its changes under experimentally simulated pathological conditions [8 - 12]. The available studies of the rats' musculoskeletal system and spine highlight this topic insufficiently. Therefore, the aim of our work is to study the structure of the normal thoracic and lumbar vertebrae in rats. 
We suppose that this study is relevant for experimental and morphological research as well as for practice.

Materials and methods of research. The objects of our study were 15 sexually mature outbred male rats, weight $80 \mathrm{~g}$, age 4,5 months. All animals were kept in a vivarium. Keeping, care, labeling, and all other manipulations were carried out in accordance with with 'European Convention for the Protection of Vertebrate Animals Used for Experimental and Other Scientific Purposes' [Strasbourg, 1985], 'Ethical principles of animal experiments', approved by the First National Congress on Bioethics [Kyiv, 2001], Law of Ukraine № 3447 IV 'On protection of animals from cruel treatment'. The study was approved by the Commission on Bioethics of Danylo Halytsky Lviv National Medical University which declared that the study meets the ethical requirements according to the order of the Ministry of Health of Ukraine № 231 of November 1, 2000 (protocol № 10 of December 26, 2011), (protocol №2 of February 20, 2012). Before sampling, the animals were sedated with dibutyl ether. Skeletalized rat bones were used as material for the macroanatomical study of the structural components of the thoracic and lumbar vertebrae. The spines were dissected after euthanasia, and then the vertebrae of the thoracic and lumbar spine were boiled for four hours, followed by careful separation of the remained soft tissues. The obtained bones were treated with a solution of hydrogen peroxide with the following photography in different projections in order to identify all anatomical structures involved in the formation of thoracic and lumbar vertebrae. Photography was made using a digital camera Nikon D 3100.

\section{Results}

The study of 15 spinal column preparations of white, outbred male rats weighing $80 \mathrm{~g}$, aged 4.5 months, conducted by the use of a set of morphological methods, revealed a lot of aspects in the normal structural components of the lower thoracic and lumbar vertebrae of rats. The spinal column of the rat consists of a set of vertebrae that form its divisions. There are 57 vertebrae in the rat spine. The cervical division is represented by 7 vertebrae, thoracic 13, lumbar - 6, sacral - 4, and caudal - 27 vertebrae (Fig. 1).

Thoracic vertebrae: the rat has 12 thoracic vertebrae which consist of a body, arches, and processes. The bodies have a prismatic shape and consist of the facets for articulation with the ribs. The facet, which is located in front of the body, connects with the facet of the adjacent vertebra forming an articulation surface for the rib. The arches of the thoracic vertebrae consist of two pedicles. Vertebral notches are well-marked. Same as in the human spinal column, vertebral notches are involved in the formation of the openings of the 
intervertebral foramina which allow the exit of the spinal nerves. From the vertebral arches branch transverse processes at the base of which are the articular processes (Fig. 2).

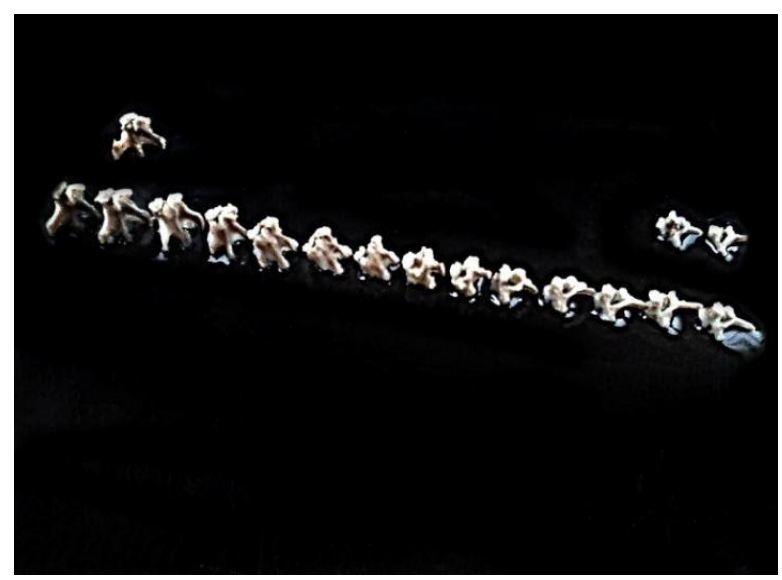

Figure.1. General structure of normal vertebral column in rats

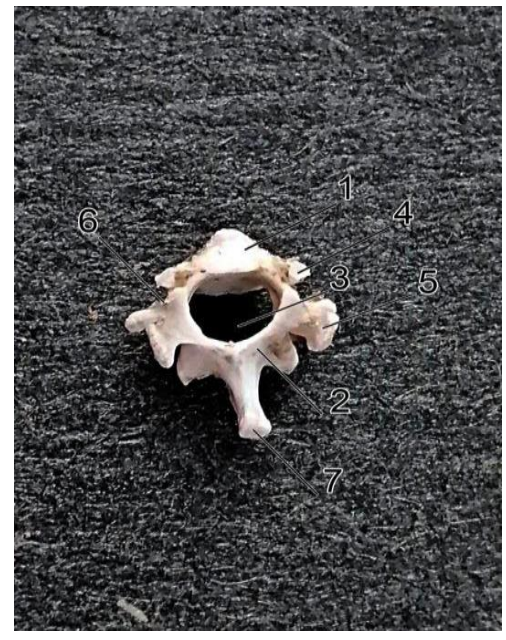

Figure. 2. General structure of normal thoracic vertebrae in rats

1. - vertebral body; 2.- arch; 3.- vertebral foramen; 4.- facet of superior articular process; 5.- transverse process; 6.- facet of transverse process for a head of a rib; 7.- spinous process.

On the surface of the transverse processes, the costal facet of the transverse process is clearly visible; it serves as a place for articulation with the head of the rib. Spinous processes are clearly visible. Spinous processes become flatter and more massive from cranial direction to caudal.

Lumbar vertebrae - there are 6 lumbar vertebrae in rats, they are more massive compared with the thoracic vertebrae (Fig. 3). 


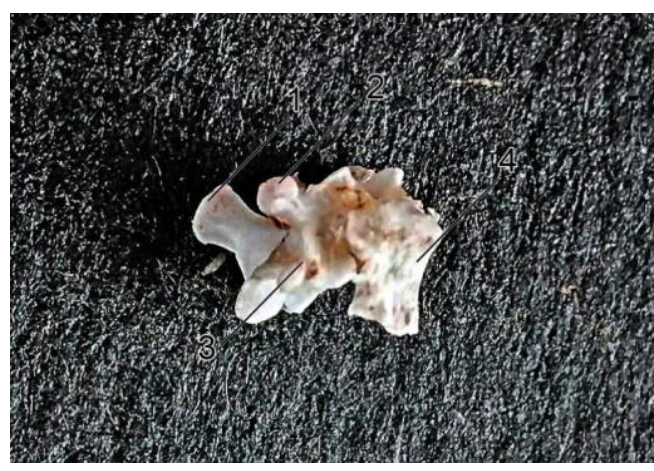

Figure 3. The general structure of normal lumbar vertebrae in rats 1.- spinous process; 2.- superior articular process; 3.- transverse process; 4. - vertebral body.

The bodies of the vertebrae become more massive from cranial to caudal (Fig. 4).

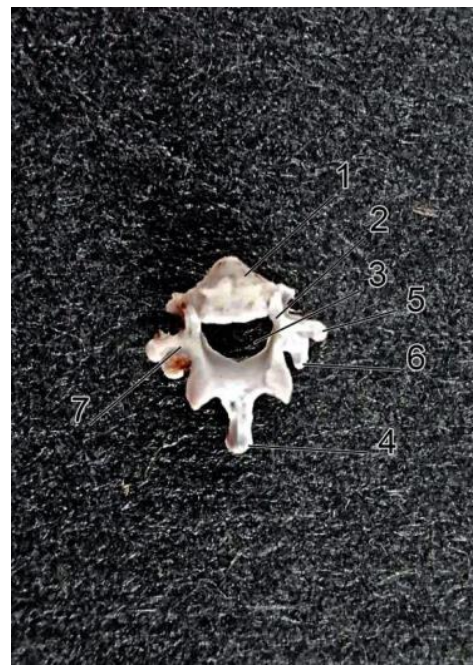

Figure 4. General structure of normal lumbar vertebrae in rats

1. - body; 2.- arch; 3.- vertebral foramen; 4. - spinous process; 5.- superior articular process; 6.- inferior articular process; 6.- transverse process.

The vertebral notches, bodies, and mammillary processes, which serve as the apophysis for fixing the tendons, are clearly distinguished among other elements of the lumbar vertebrae (Fig. 4). The peculiarity of the spinous processes of the lumbar vertebrae is that they are broad and thick, their length increases from cranial direction and then decreases again.

\section{Conclusions}

As a result of our study, we identified the morphology of normal vertebrae of the thoracic and lumbar spine in rats. We studied a set of morphological components of the thoracic and lumbar vertebrae of the normal spinal column in rats. 


\section{References}

1. Paltov Y. Access method and injection of X-ray contrast in arterial vessels of the maxillofacial area in rat // Messenger of morphology.-2003. - Vol.9, №1. - P.151-152.

2. Paltov Y.V. Morphological features of the anatomy of the neck arterial bed and maxillofacial area in normal rat // Scientific Messenger of Stepan Gzhytskyi National University of Veterinary Medicine and Biotechnologies Lviv. - 2004. - Vol.6 (1), №1. P.113-119.

3. Paltov Y.V. Atypical variant of the occipital region vessels branching in rat // Abstracts. International scientific-practical conference of young scientists, October 14-16, 2004. - Odessa. - 2004. - P.5.

4. Onysko R.M. Anatomical features of the small intestine structure in normal rat/ R.M. Onysko // Messenger of Ukrainian Medical Dental Academy. - 2009. - T. 9, Vol. 4 (28), part 3. - P. 109 - 111.

5. Onysko R.M. Morphological features of the small intestine arterial bed in normal rat / R.M. Onysko // Messenger of morphology. - 2009. - Vol.15, № 2. - P. 338 - 341.

6. Onysko R.M., Kryvko Yu..Ya., Paltov Y.V. X-ray vasographic studies of the arterial bed of the main vessels of the small intestine in normal rats // "Relevant problems of functional morphology and integrative anthropology". May 20 - 21, 2009. - Vinnytsia. - 2009. - P. 222.

7. Onysko R.M., Kryvko Yu.Ya., Paltov Y.V. Morphometric study of the branches of the hemomicrocirculatory tract in the small intestine in normal rats // International scientific conference of students and young scientists dedicated to the 150th anniversary of the birth of prof. M.F. Gamalei. Youth of the future medicine. - April 23 - 24, 2009. - Odessa. - 2009. - P. 27.

8. Onysko I.O. Microstructural changes in the tongue under small doses of opioids influence during 70 and 84 days (experimental study) / I.O. Onysko, O.Ye. Mayevsky // Ukrainian Morphological Almanac. - 2013. - Volume 11. №2. - P. 72 - 76.

9. Onysko I.O. Changes at the electron microscopic level in the tissues of the tongue at the end of $6^{\text {th }}$ and $8^{\text {th }}$ week of the small doses of opioids influence (experimental study) / I.O. Onysko, A.P. Korol, O.Ye. Mayevsky, R.M. Onysko // Biomedical and Biosocial Anthropology. - 2013. - №2. - P. 13 - 19.

10. Yakymiv N. Ya. Microstructural characteristics of the iris-corneal angle of the eyeball in rats under opioid influence / N. Ya. Yakymiv, Yu. Ya. Kryvko // World of Medicine and Biology. - 2013. - № 4. - P. 120-124. 
11. Paltov Y. Dynamics of the onset of pathological changes in the retinal layers at the end of the first week of opioid exposure / Y. Paltov, Y. Kryvko, V. Fik, I. Vilkhova, Kh. Ivasivka, M. Pankiv, K. Voitsenko // Deutscher Wissenschaftsherold. German Science Herald. - 2016. - №2. - p. 30 - 33.

12. Paltov Y. Pathomorphological manifestations in the retina layers during one week of opioid analgesic exposure / Y. Paltov, Y. Kryvko, V. Fik, I. Vilkhova, Kh. Ivasivka, M. Pankiv, K. Voitsenko // Natural Science Readings abstracts booc (May 19 - 22, 2016, Bratislava). - p. 25 - 27. 